\title{
Ex - Libris
}

Devocionario Romántico, por Carlos Préndez Saldias. Imprenta Universitaria, Santiago, 1926.

Libro de pasión, de gracia; de humor y, sobre todo, de ponderada poesia.

Préndez no abandona sus gestos bizarros, esa nola que él usa, fal vez más que por diferenciar sus ediciones del cansado gris de la multifud literaria, porque piense que en Chile hay que buscar a la poesía más pura el perdón de las gentes, añadiendo entre titulos y dedicatorias alguna pirueta y alguna sonrisa.

Es como si quisiera decir al vulgo:

- ¿Veis? En çuanto hombre, también yo piso un suelo de realidad, sé sonreir a esta chifladura y relegarla en alegre broma a ese mundo intimo donde todos sentimos en elevación.

$\mathrm{Y}$ no por este humor para entonar en el ambiente, dejamos de reconocer que nos hallamos con un alto poeta en cuanto nos recogemos a leerlo.

El volumen, pequeñito, primoroso, azul y oro, con todas las características del breviario elegante, comienza con esta

\section{INDULGENCIA}

El Dios Amor concederá cien crepúsculos de plenifud amorosa al que rece en las páginas de esfe breviario. 
Pasa por ella nuestra vista y nos ponemos regocijados de ánimo.

Mas, a poco de rezar en el devocionario plegarias, salves. credos, letanias y un conjunto de horas canónicas del amor. tenemos unción en el alma y nos entregamos a las .Cinco Medilaciones, con que el libro termina, misticamente y afinados de belleza.

Cada lector, al llegar alli, dirá con el poeta:

Solo por la montaña

blanca de luna, siento

que la voz de los hombres

es apenas un eco

en mi vida ardorosa

de corazón adentro.

Y. olvidado el cascabel con que Préndez quiso excusar su hondura, amará este espíritu y le rendirá admiraciọn.

DESOLACIÓN, por Gabriela Mistral. Editorial Nascimento, Santiago, 1926.

Nos llega la tercera edición de este libro en que nuestra gran lirica ha reunido lo más intenso de su versọ y de su prosa. El libro es tan conocido que nadie ignora que forma el plinto de una repulación mundial. Pero esta cdición tiene condiciones que la hacen definitiva. La poetisa ha seleccionado los poemas que aparecian en las anteriores; ha corregido versos, suavizando ritmos y bruñendo dicciones; en las prosas, la revisión ha sido tal, que algunas parecen nuevas.

Se trata, repetimos, de una edición definitiva que bien merece ser la'sustituta de las anteriores en todas las bibliotecas. 